\title{
PRAYING THE TRADITION: THE ORIGIN AND USE OF TRADITION IN NEHEMIAH $9^{1}$
}

\author{
Mark J. Boda
}

The goal of this dissertation was to identify those who were responsible for the prayer in Nehemiah 9, and how they used the traditions of Israel.

An investigation of the Gattung to which Nehemiah 9 belonged laid the groundwork for a traditional historical evaluation of the composition. Nehemiah 9 was identified with a series of prayers which represent a transformation of the classical Hebrew Gattung of lament: Late Repentance Prayer (Ezra 9; Neh. 1, Dan. 9, Ps. 106). Besides a long list of shared forms and vocabulary, consistent themes were evident: covenant, land, law. The purpose of these compositions was to bring an end to the devastating effects of the fall of the state: an end to captivity, oppression or the sorry condition of Palestine. An activity that accompanied nearly all of these compositions was fasting. The emergence of a regular cycle of day(s) of fasting among the Mesopotamian and Palestinian exilic communities showed not only the importance of fasting in this period but also a setting for Late Repentance Prayer.

A traditio-historical evaluation of this Gattung revealed that Priestly/Ezekielian circles supplemented and superseded a Deuteronomistic foundation. Although there was ample evidence of Deuteronomistic vocabulary and concepts, there was a substantial number of Priestly/Ezekielian elements. The various representatives of the Gattung also revealed a consistent approach to the to the Pentateuch: synthesis of either legal or historical traditions.

${ }^{1}$ M.J. Boda, Praying the Tradition: The origin and use of tradition in Nehemiah 9 (unpublished Ph.D. thesis, University of Camrbidge, 1995); supervisors: Prof. H.G.M. Williamson and Dr. G. I. Davies. 
By determining the formal and traditio-historical character of the Gattung this evaluation was able to identify more clearly the unique character of Nehemiah 9 in relation to its Gattung. The first step in the traditio-historical analysis of Nehemiah 9 was to determine the tradition boundaries of the composition. Between an introductory call to worship (9:5) and concluding request for help with confession (9:32-37), the prayer presents successive traditions guiding the reader from the creation of the world to the fall of the state. Although it is intended to be read as a single account, clear boundaries could be discerned between the traditions. These boundaries had been accepted universally for the traditions of creation (6), Abraham (7-8) and exodus (9-11). The investigation concluded that the wilderness tradition includes 9:12-23 with the Sinai and 'forty year' traditions integrated into this tradition complex. The conquest tradition is considered in the introduction to the larger tradition complex: life in the land (24-31).

These results were only confirmed by a closer look at the way in which the traditions are recited in Nehemiah 9. Nearly all commentators on Nehemiah 9 have identified in vv. 26-31 the presence of the historical sequencing model used in the book of Judges. A few scholars have sought to force this sequencing model on to the entire prayer in Nehemiah 9, in particular on to the wilderness tradition. However a closer look at the wilderness tradition, as well as other compositions where tradition is recited, resulted in the identification of a second sequencing model used in the Hebrew Bible. The sequencing model from the book of Judges was named the 'discipline model', but this was contrasted to a sequencing model named the 'patience model'. The patience model was illustrated from Deuteronomy 32 and Ezekiel 20, and could be discerned in Nehemiah 9 in the wilderness tradition. In the discipline model, when human rebellion occurs, Yahweh responds with punishment which has as its goal the repentance of the people through a cry for help. In the patience model when human rebellion occurs, Yahweh does not respond with punishment (although he may ponder it), but rather with patience and grace. The discipline model was seen as extremely important in the prayer of Nehemiah 9 in order to 
strengthen the request beginning in v. 32. The discipline model is used in succession in vv. 24-31 and the final time it is employed it is cut off half way through the cycle. The request of v. 32 is seen as an attempt to reactivate the cycle representing the 'cry' of the people in the hope of Yahweh's grace. The patience model, however, is used in the wilderness tradition. The key to its use there is the promise of land to Abraham ( $\mathrm{v}$. 8). The promise of land is secure because of the faithfulness of Abraham, and Yahweh is thus patient until the people are securely in the land. Once they are in the land, the discipline model is used to explain why they have been thrust out of the land. The patience model is key to their hope for the future: the promise to Abraham is secured, but so also is the discipline model as it sets up the request. Both of these models are traced to their source in prophetic circles.

After determining the tradition boundaries of the prayer and the way in which these traditions are recited, attention now turned to a detailed traditio-historical evaluation of Nehemiah 9. The prayer presented a remarkably consistent picture throughout. The prayer presupposed the Pentateuch in a very similar form to that possessed today. Additionally, evidence from Judges suggested that it was in its present form and the many allusions to 2 Kings 17 also point in the direction of a substantial collection of the Deuteronomistic history.

The most universally accepted conclusion about the traditio-historical background of the prayer was affirmed in our analysis: it is dominated by Deuteronomistic idiom. Nevertheless, it is the universality of this conclusion that was seen to blind many of scholars to the most illuminating evidence for the traditio-historical background of Nehemiah 9:5-37. Most scholars have not seen the widespread presence of Priestly/Ezekielian vocabulary in this prayer, nor have noticed numerous examples of Deuteronomistic idioms which have been subtly transformed by Priestly/Ezekielian notions and vocabulary. This evidence confirms the membership of this prayer in the Gattung of Late Repentance Prayer where the same combinations were found. However a distinguishing mark for Nehemiah 9 was contacts established with Zechariah $1: 1-6 ; 7: 1-8,23$. The presence of many of these contacts in the 
request section of the prayer was significant because in the section freed from the constraints of reciting traditional material, Zecharian idiom shone through.

The traditio-historical analysis was then applied to the two basic questions of this work: who is responsible for this composition and how is tradition being used? By examining Nehemiah 9 in its literary context, it was demonstrated that the prayer originated prior to the work of Ezra and Nehemiah. Pursuing this more closely, the early Persian period was identified as the most likely candidate and during this period among those associated with Zechariah. Within this era the period immediately preceding the ministry of Haggai and Zechariah was favoured, but the period after the disappearance of Zerubbabel but before Ezra could not be discounted. Thus Nehemiah 9 is a prayer which arose within the early restoration community in the Persian province of Yehud. It is representative of a type of prayer which reveals close affinities with Priestly/Ezekielian emphases drawing on a base of Deuteronomistic orthodoxy. It reveals the composite nature of a community struggling for it's existence on the frontiers of the Persian Empire, confirming the presence of divergent groups forced together through adversity.

The evidence was also applied to the question of how tradition was being used in Nehemiah 9. Although tradition is used for the purposes of praise and confession, ultimately it is shaped by the agenda of request. The tradition is related in such a way as to strengthen the request of the suppliant. This prayer reveals a community which was embracing its documents as Scripture, treating at least the Pentateuch as an authoritative whole and synthesising its parts through careful exegesis. In this way, we see a community praying the tradition and in so doing revealing their commitment to that tradition as Scripture. This commitment to the tradition does not mean tradition has become static. The Persian Jewish community continued to reshape the tradition into an effective tool for gaining the ear of their God. Inscripturated tradition is creatively related to ever new situations of need among the people of Yahweh. 